\title{
In silico Cytotoxicity of Taxol-like Weighted Compounds Contained in Sea Cucumber Using PLANTS against Protein of Human Kinesin-8
}

\author{
Broto Santoso \\ Universitas Muhammadiyah Surakarta \\ Sukoharjo, Indonesia \\ broto.Santoso@ums.ac.id
}

\begin{abstract}
East Indonesia has abundant natural resources, one of which is sea cucumber. This organism has anticancer activity but it has not been explored further. Based on the database of Traditional Chinese Pharmacology System, it has 586 compounds. Thirty-seven of these compounds have molecular weight similar to taxol, an anticancer agent. This study confirms the anticancer activity of the compounds in silico. Target proteins, its natives, and the 37 compounds were prepared to be suitable to PLANTS software. Molecular docking for these chemicals was performed by PLANTS. The results were analyzed and visualized through PyMOL-PLIP adopting mass center and best radius sphere of native ligands from previous studies. The percentage of the ligand tests that have best PLANTS score compared to the natives of $50 \mathrm{cu}$, $50 a m$, and 50 ge were $73.0 ; 56.8$; and $8.1 \%$, respectively. Compound named HPC-3-B has the lowest score, -127 to -106 $\mathrm{kcal} / \mathrm{mol}$ in all treatment conditions. Other compounds which have low score are CEG-3, kalsigerosida-D1, kukumariosidaA3_3, pseudostikoposida-B, holothurin-B2, and psolusosida-B with PLANTS score of -128.5-(-104,5), -111.9, -111.3, -102.3, 101.1 , and $-99.8 \mathrm{kcal} / \mathrm{mol}$, respectively. The results of this study confirm that the several compounds in sea cucumber have potential as anticancer agents.
\end{abstract}

Keywords- Human Kinesin-8 Protein, PLANTS, Sea cucumber, TAXOL.

\section{INTRODUCTION}

In 2015, national businesses in the fields of agriculture, forestry and fisheries had the second largest growth rate $(5.09 \%)$ after financial and insurance services $(7.03 \%)$. Contributions in the fields of agriculture, forestry and fisheries are also the second largest (close to 15\%) with a value of 434 billion rupiah of the total national Gross Domestic Product in the third quarter of the same year [1]. Sea cucumbers are reported to be one of the fishery commodities that spread in 20 coastal areas, and most are in Eastern Indonesia such as Sulawesi, Maluku, Bali, Lombok, East Papua, Nusa Tenggara Timur (NTT), and Nusa Tenggara Barat (NTB) [2]. Dompu, Bima, and NTB have the potential to produce 350 tons sea cucumber per year [3]. South Sulawesi has a large sea cucumber export value in 2007 of $\$ 15$ million which was $1 / 6$ lower than that of in 2004 (\$94 million) due to lack of government attention to its conservation efforts [4].

The potential of sea cucumber biological activity is still minimally explored. Ruiz-Torres et al. (2017) reported that sea cucumbers have anticancer activity against P388, A549, MKN-28, HCT-116 and MCF-7 cells. The compound thought to be responsible for the activity is glycosylated triterpene [5]. Razi et al (2018) found that sea cucumbers have bioactive compounds against hepatocellular carcinoma [6]. Virtual screening of the chemical compounds in sea cucumbers indicates the potential to proceed to laboratory testing stages [7]. Paclitaxel or taxol is a unique anticancer compound because it does not meet Lipinski's rules like other potential ligands. Based on the database of Traditional Chinese Pharmacology System (TCMSP), sea cucumbers contain 586 compounds. Thirty-seven of these compounds have molecular weight (between 750-1000 amu) similar to taxol, an anticancer agent [8]. This study confirms the anticancer activity of the compounds in silico.

\section{METHODS}

The thirty-seven of sea cucumber molecules was converted from their original form (pictures) to supported files for PLANTS and adjusted to their original structures by online OSRA [9]. Target proteins which are obtained from PDB database [10], their natives, and the selected compounds were prepared to be suitable to PLANTS [11] software using Chimera [12]. Molecular docking for these chemicals were performed by PLANTS. The results were analyzed and visualized through PyMOL-PLIP [13-14] adopting mass center and best radius sphere of native ligands from previous studies [15].

\section{RESULTS}

The percentage of the thirty-seven ligand tests that have best PLANTS score compared to the natives of 5ocu, 5oam, and 5ogc were 73.0; 56.8; and 8.1\%, respectively (Figure 2). Previous studies recommend to use the results of the $5 \mathrm{ogc}$ target protein because it has a larger, deeper and representative binding site pocket volume with a greater amount of residue involved in molecular docking [15]. Furthermore, the PLANTS score from the native has a better value than the PLANTS score native of other two target proteins. 


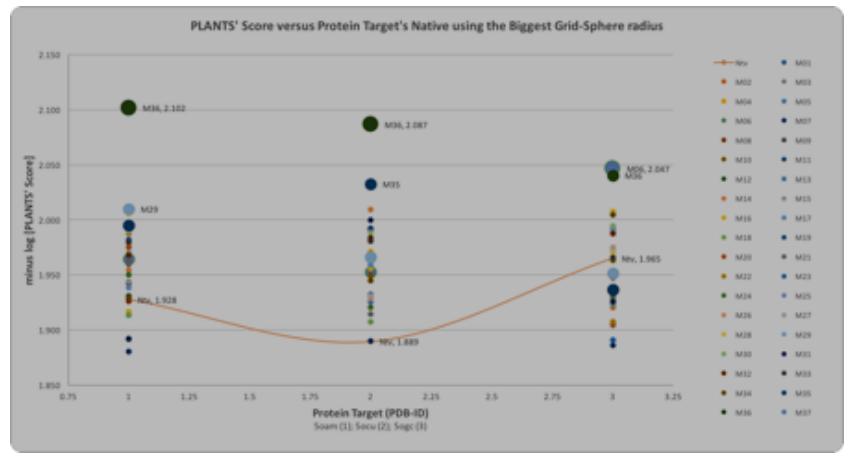

Figure 1. PLANTS score of sea cucumber's selected compounds against natives' molecule of target protein using the biggest gridsphere radius.

Figure 1 shows that the highest rank PLANTS score of each protein has lower value than figure 2 presented which using the best grid-sphere radius. It was also appear in the lowest grid-sphere radius (Figure 3). This confirms that the validation of the virtual ligand-protein interaction space needs to be done to obtain the PLANTS radius number (sphere) or the value of the $\mathrm{x}, \mathrm{y}, \mathrm{z}$ gridbox other docking software.

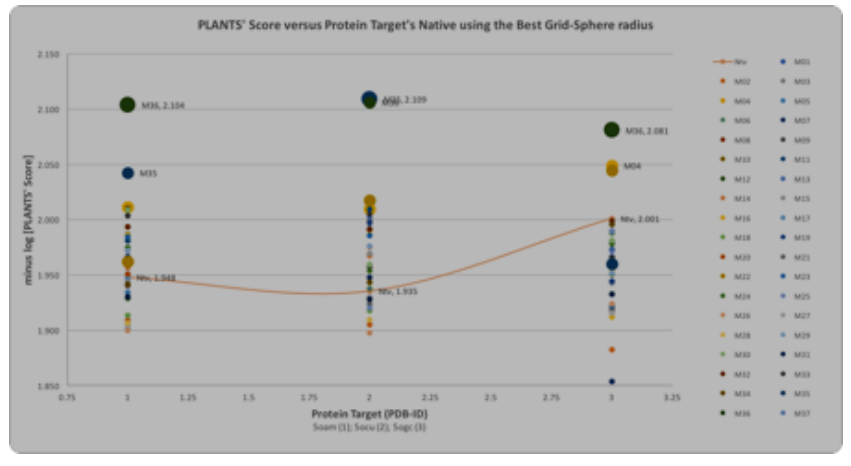

Figure 2. PLANTS score of sea cucumber's selected compounds against natives' molecule of target protein using the best grid-sphere radius.

Compound named HPC-3-B has the lowest score, -127 to $-106 \mathrm{kcal} / \mathrm{mol}$ in all treatment conditions. This compound has a number of bonds that can be rotated more so that the high level of flexibility during molecular docking is useful for adjusting the space of the target protein binding site pocket. Figure 4 shows the 3-dimensional position of HPC3 -B to the target protein.

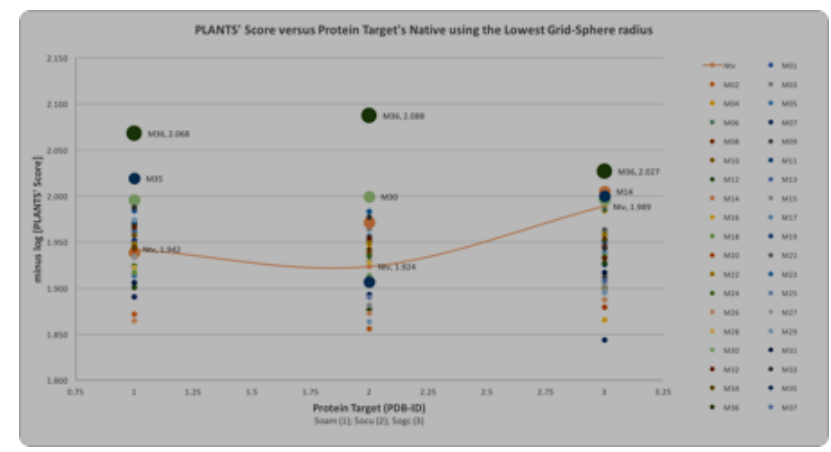

Figure 3. PLANTS score of sea cucumber's selected compounds against natives' molecule of target protein using the lowest gridsphere radius.
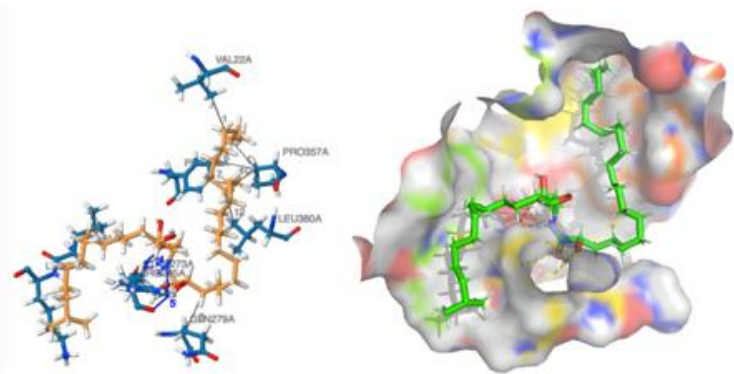

Figure 4. The results of the calculation of ligand-protein interaction using PLIP (left) and 3-dimensional visualization of HPC-3-B ligands on the target protein $5 \mathrm{ogc}$ (right).

The HPC-3-B molecule has hydrogen bonding interactions with THR273 and ARG275 residues. The last residue was also observed to have hydrogen bonds with calcigeroside-D1 ligands in addition to SER277 residues. The two ligands have the same hydrophobic interaction with residues GLN279 and LEU360.

Other compounds which have low score are CEG-3, calsigerosides-D1, cucumariosides-A3_3, pseudostichoposide-B, holothurin-B2, and psolusoside-B with PLANTS score of -128.5-(-104,5), -111.9, -111.3, -102.3, -101.1, and $99.8 \mathrm{kcal} / \mathrm{mol}$, respectively (Figure 1-3).

\section{CONCLUSION}

The results of this study confirm that the several compounds in sea cucumber have potential as anticancer agents.

\section{ACKNOWLEDGMENT}

This research is one of article which is published by Universitas Muhammadiyah Surakarta of Sukoharjo.

\section{REFERENCES}

[1] R. R. Damanti and M. Nirmalanti (Editor), "Analisis Data Pokok Kelautan dan Perikanan 2015”, Pusat Data, Statistik, Informasi. Kementerian Kelautan dan Perikanan Republik Indonesia, 2015, pp. .

[2] A. Dermawan, A. Setyastuti, and S. T. Hartati (Editor), "Rencana Aksi Nasional (RAN) Konservasi Teripang Periode 1: 2016-2020", Direktorat Konservasi dan Keanekaragaman Hayati Laut, Direktorat Jenderal Pengeloalaan Ruang Laut, Kementerian Kelautan dan Perikanan Republik Indonesia, 2015, pp.68-73.

[3] P. Darsono, "Sumberdaya Teripang dan Pengelolaannya", Oseana, Vol. XXVIII, No. 2: 1-9. 2009.

[4] S. Tahe, "Present Status Produksi dan Budidaya Teripang di Sulawesi Selatan", Prosiding Forum Inovasi Teknologi Akuakultur, pp. 229-37. 2013.

[5] V. Ruiz-Torres, J. A. Encinar, M. Herranz-Lopez, A. Perez-Sanchez, V. Galiano, E. Barrajon-Catalan, and V. Micol, "An Updated Review on Marine Anticancer Compounds: The Use of Virtual Screening for the Discovery of Small-Molecule Cancer Drugs", Molecules, 22, 1037, doi:10.3390/molecules22071037. 2017.

[6] N. S. Razi, Y. Arast, M. Nazemi, and J. Pourahmad, "Selective Toxicity of Non-polar Bioactive Compounds of Sea Cucumber (Holothuria sabra) Extracts on Isolated Mitochondria and Hepatocytes of Induced Hepatocellular Carcinoma Rat Model", Asian Pacific Journal of Cancer Biology, Vol 3, Issue 1, 25-36. 2018.

[7] T. L. Wargasetia, S. Permana, and N. Widodo, "Potential use of compounds from sea cucumbers as MDM2 and CXCR4 inhibitors to 
control cancer cell growth", Experimental and Therapeutic Medicine, 2018, 16(4), 2985-91. doi:10.3892/etm.2018.6588.

[8] J. Ru, P. Li, J. Wang, W. Zhou, B. Li, C. Huang, P. Li, Z. Guo, W. Tao, Y. Yang, X. Xu, Y. Li, Y. Wang, and L. Yang, "TCMSP: a database of systems pharmacology for drug discovery from herbal medicines" J Cheminformatics. 2014, 6(1):13

[9] I. V. Filippov, and M. C. Nicklaus, "Optical Structure Recognition Software To Recover Chemical Information: OSRA - An Open Source Solution", Journal of Chemical Information and Modeling, 2009, 49(3), 740-743. doi: 10.1021/ci800067r.

[10] H. M. Berman, J. Westbrook, Z. Feng, G. Gilliland, T. N. Bhat, H Weissig, I. N. Shindyalov, and P. E. Bourne, "The Protein Data Bank. Nucleic Acids Research", 2000, 28: 235-242.

[11] O. Korb, T. Stützle, and T. E. Exner, "Empirical Scoring Functions for Advanced Protein-Ligand Docking with PLANTS", J. Chem. Inf. Model., 2009, 49, 84-96.
[12] E. F. Pettersen, T. D. Goddard, C. C. Huang, G. S. Couch, D. M. Greenblatt, E. C. Meng, and T. E. Ferrin, "UCSF Chimera--a visualization system for exploratory research and analysis", J Comput. Chem. 25(13), 1605-12. 2004.

[13] The PyMOL Molecular Graphics System, Version 2.1.0 Schrödinger, LLC.

[14] S. Salentin, S. Schreiber, V. J. Haupt, M. F. Adasme, and M. Schroeder, "PLIP: fully automated protein-ligand interaction profiler", Nucl. Acids Res. 43 (W1): W443-W447. DOI: 10.1093/nar/gkv315. 2015.

[15] B. Santoso, "Validation of Computing Space of Native Compound which does not Fulfill Lipinski's Rule Using PLANTS", The 8th University Research Colloquium, LPPM Universitas Muhammadiyah Purwokerto, Indonesia, September 4th, 2018. 